\title{
CONE-BEAM COMPUTED TOMOGRAPHY IN THE DIAGNOSIS OF NASAL CAVITY FUNGUS BALL
}

\author{
Serova N.S., Avetisyan E.Y., Shebunina A.B., Lisavin A.A, Eremeeva K.V.
}

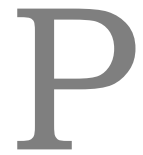

urpose. To present the relevance of cone-beam computed tomography (CBCT) in diagnostics of nasal cavity fungus ball before surgery.

I.M. Sechenov First

Materials and methods. The clinical observation of the patient with nasal cavity fungus ball is provided. Patient's examination included anterior rhinoscopy, forward-viewing endoscopy, and CBCT.

Results. After comprehensive clinical examination of the patient including CBCT accurate diagnosis was established: fungus ball in the left half of the nasal cavity. Endoscopic foreign body removal had been carried out with endotracheal anesthesia. It is required to perform histological examination.

Conclusion. The presented clinical case demonstrates the importance of CBCT application in pre-admission diagnostics of nasal cavity fungus ball..

Keywords: fungus ball, nasal cavity, cone-beam computed tomography.

Corresponding author: Shebunina A.B., e-mail: anna.shebunina@gmail.com

For citation: Serova N.S., Avetisyan E.Y., Shebunina A.B., Lisavin A.A, Eremeeva K.V. Use of cone-beam computed tomography in the diagnosis of nasal cavity fungus ball. REJR 2018; 8 (2):222-225. DOI:10.21569/2222-7415-2018-8-2-222-225.

Received: $\quad 30.03 .2018 \quad$ Accepted: $\quad 08.06 .2018$

\section{КОНУСНО-АУЧЕВАЯ КОМПЬЮТЕРНАЯ ТОМОГРАФИЯ В АИАГНОСТИКЕ ГРИБКОВОГО ТЕАА ПОАОСТИ НОСА}

\section{Серова Н.С., Аветисян Э.Е, Шебунина А.Б., Аисавин А.А., Еремеева К.В.}

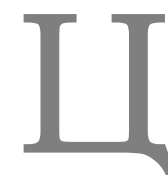

ель исследования. Представить актуальность применения конусно-цучевой компьютерной томографии (КАKT) в предоперационной диагностике грибкового тела полости носа.

Материалы и методы. Приводится клиническое наблюдение пациента с грибковым телом полости носа. Исследование пациента включало переднюю риноскопию, эндоскопическое исследование полости носа при помощи торцевого эндоскопа и $\mathrm{K} \Lambda \mathrm{KT}$.

Результаты. После всестороннего клинического осмотра пациента был установцен диагноз: грибковое тело мевой половины полости носа. Удаление грибкового тела осуществлялось эндоскопически под комбинированной эндотрахеальной анестезией. Дополнительно было выполнено патогистологическое исследование.

Вывод. Представленный клинический случай демонстрирует актуальность применения $\mathrm{K} \Lambda \mathrm{KT}$ на дооперационном этапе диагностики грибковых теА полости носа.

Ключевые слова: грибковое тело, полость носа, конусно-цучевая компьютерная томография.

Контактный автор: Шебунина А.Б., e-mail: anna.shebunina@gmail.com

Для иитирования: Серова Н.С., Аветисян Э.Е, Шебунина А.Б., Аисавин А.А., Еремеева К.В. Опыт применения конусно-лучевой компьютерной томографии в диагно- 
стике грибкового тела полости носа. REJR 2018; 8 (2):222-225. DOI:10.21569/2222-

7415-2018-8-2-222-225.
Статья получена:
30.03.2018
Статья принята:
08.06.2018

\section{I}

ntroduction. Fungal diseases of ENT organs are an actual problem of modern otorhinolaryngology. The main forms of ENT organs fungal diseases are pharyngomycosis, otomycosis, laryngomycosis, and fungal rhinosinusitis [1, 2]. The increase in the mycosis incidence is associated with many factors, including the widespread application of antibacterial drugs and steroids in medical practice. The majority of fungi

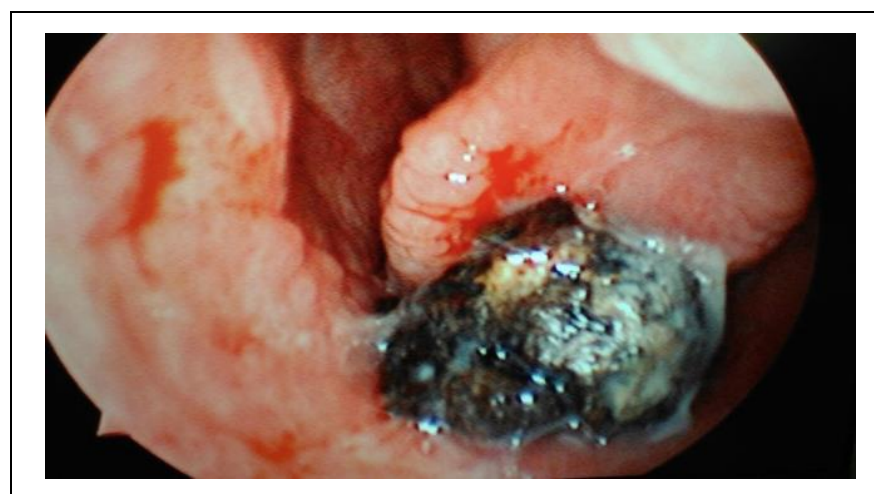

Fig. 1. Foto. Endoscopy of the nasal cavity.

A dense formation in the left inferior nasal meatus. The left inferior turbinate is enlarged.

Рис. 1. Фотография. ЭнАоскопия полости носа.

Пцотное образование в передних отделах мевого нижнего носового хода. Аевая нижняя носовая раковина увеличена.

causing mycoses of ENT organs are opportunistic pathogens that cause the disease when immunological reactivity of the body decreases [3]. The main pathogens of ENT organs fungal diseases are mold fungi of the Aspergillus genus (up to 78\%) and yeast-like fungi of the Candida genus. [4]. According to Russian authors, the incidence of fungal nasal and paranasal sinus infections among all inflammatory diseases of this region is up to $13 \%$ [5]. However, it should be noted that there are single references to isolated fungal lesion of the nasal cavity in the world literature [6]. Symptoms of this disease are non-specific and usually include difficulty in nasal breathing, nasal stuffiness and swelling of the nasal mucosa. Diagnosis of the nasal cavity fungus ball should be comprehensive, including clinical examination, endoscopy, radiological diagnostics and histological examination. Computed tomography is an important part of the nasal cavity fungus ball diagnostics and planning of surgical treatment.

We describe a clinical case of a 29-year-old patient with a nasal cavity fungus ball, which required surgical treatment.

Purpose. To present the relevance of conebeam computed tomography (CBCT) in diagnostics of nasal cavity fungus ball before surgery.

Materials and methods. The clinical observation of the patient with nasal cavity fungus ball is provided. Patient's examination included anterior rhinoscopy, forward-viewing endoscopy, and CBCT.

Case report. A 29-year-old patient was admitted to Clinic of ear, nose and throat diseases of Sechenov University with complaints of running nose, difficulty in nasal breathing, alternating nasal stuffiness and recurrent rinorrhea for a long time. The patient constantly uses nasal decongestants for many years. In past history the patient underwent rhinoseptoplasty (about 5 years ago). On examination change of the external nose shape, nasal arch deviation to the left, and the deviated nasal septum were found. The nasal septum is deviated to the right with the formation of a crest leaning against the inferior turbinate bone. Nasal passages are narrowed. Nasal cavity mucosa is pink, edematous.

At endoscopy there is a dark brown dense formation under the inferior turbinate penetrating the mucous membrane of the nasal cavity floor. The left inferior turbinate is enlarged. There is a poor mucous discharge in the nasal passages.

CBCT of the nasal cavity and paranasal sinuses showed the presence of formation (presumably fungal etiology) with a high density with distinct irregular contours in the region of the left inferior turbinate, not adjacent to bone tissues, $10.1 \mathrm{~mm} \times 15.2 \mathrm{~mm} \times 10.7 \mathrm{~mm}$ in size. Mucosal hypertrophy in the lower parts of both maxillary sinuses (in the right up to $2.3 \mathrm{~mm}$, in the left up to $2.1 \mathrm{~mm}$ ), in the left posterior cells of the ethmoidal labyrinth up to $2.1 \mathrm{~mm}$ is noted. Also, deviated nasal septum to the right up to $5.3 \mathrm{~mm}$ is detected. The right nasal passage is narrowed. The nasal mucous membrane is thickened.

The patient underwent surgical treatment. Endoscopic removal of the formation and reseptoplasty were performed. The formation was removed from the left side of the nasal cavity. It was 


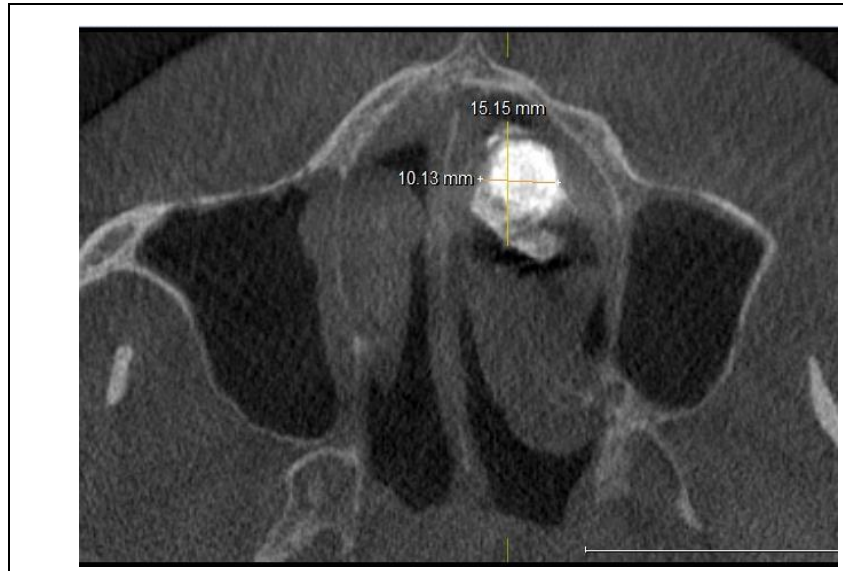

Рис. 2 a (Fig. 2 a)

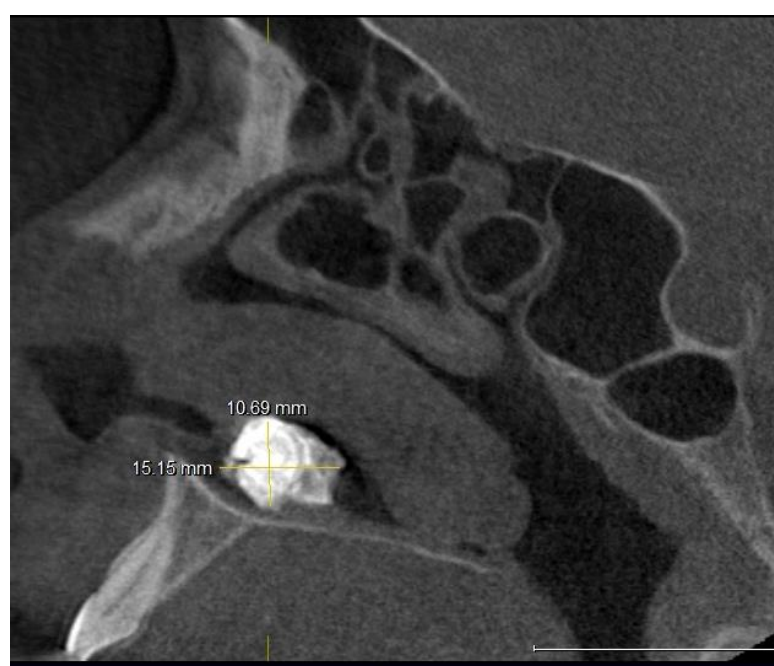

Рис. 2 с (Fig. 2 в)

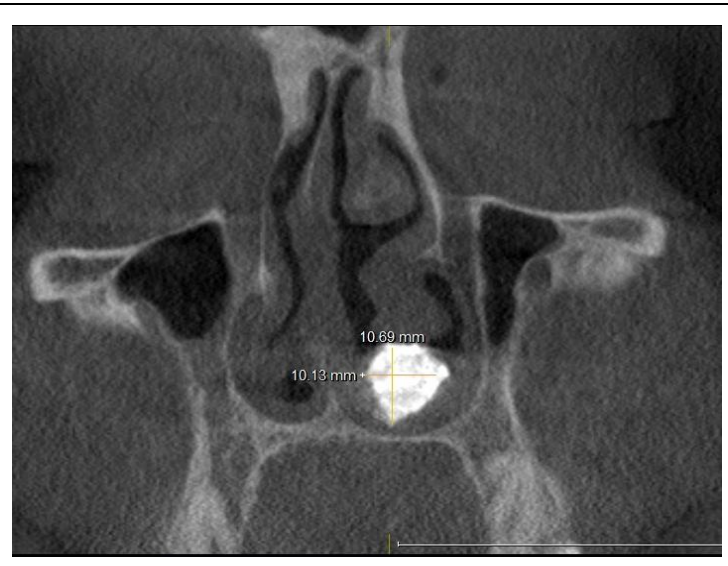

Puc. 2 b (Fig. 2 б)

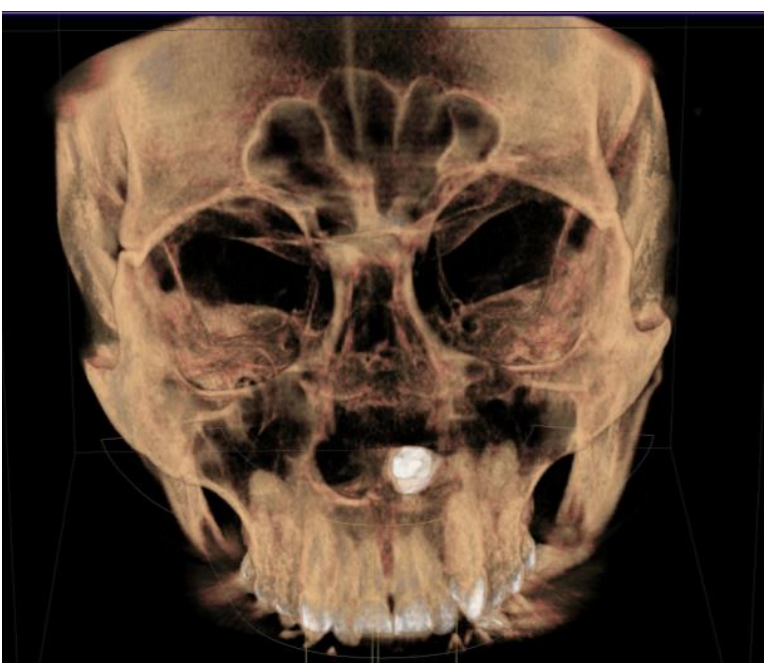

Рис. 2 d (Fig. 2 г)

Fig. 2. $C B C T$, axial plane (a), frontal plane (b), sagittal plane (c), 3D-model (d).

High density formation with distinct irregular contours in the region of the left inferior turbinate.

Рис. 2. КАКТ, аксиальная п^оскость (а), коронарная плоскость (б), сагиттальная проскость (в), 3D-реконструкция (r).

Образование высокой плотности с четкими неровными контурами в области мевой нижней носовой раковины.

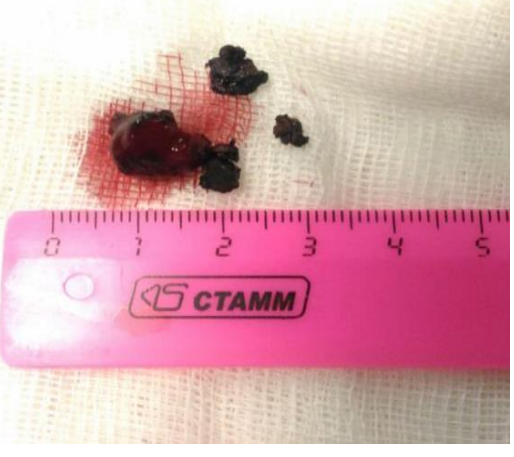

Fig. 3. Photo. Gross specimen.

The Fungus ball.

Рис. 3. Фотография. Макропрепарат.

Грибковое тело. dark brown dense structure about $1.5 \mathrm{~cm} \mathrm{x} 1.5$ $\mathrm{cm}$ in size located under the inferior turbinate closer to the nasal cavity floor.

The histological examination of tissues showed nasal cavity fungus ball.

The patient made a full recovery with complete resolution of his symptoms after 2 weeks.

Discussion.

The capabilities of cone-beam computed tomography $(\mathrm{CBCT})$ and multislice computed tomography (MSCT) in the diagnosis of fungus balls of the nasal cavity and paranasal sinuses are completely comparable to each other and significantly exceed the traditional X-ray techniques for diagnostic information. The advantages of CBCT and MSCT in comparison with traditional radiography also include the lack of superposition, high contrast resolution and the possibility of obtaining 3D reconstructions [7]. Studies confirming the 


\section{RUSSIAN ELECTRONIC JOURNAL OF RADIOLOGY}

possibility to establish a diagnosis of the fungus ball only on the basis of CT data are described [8]. This is due to the presence of certain CT - features of the fungus ball - a heterogeneous density of formation due to combination of contents soft tissue density (the presence of fungus ball masses and inflamed mucosa) with high-density inclusions relevant to the deposition of calcium salts and the formation of mycotic stones [9-11].

Conclusion. The presented clinical case demonstrates the informative value of CBCT in the

\section{References:}

1. Kryukov A.I., Turovsky A.B., Dimova A.D., Shadrin G.B.. Mycosis in otorhinolaryngology. Consilium Medicum. 2004; 6 (4): 56 (in Russian).

2. Kunel'skaia V.Ia. State of the art diagnosis and treatment of ENT mycotic diseases. Vestnik Otorinolaryngologii. 2009; 4: 757 (in Russian).

3. Klimko N.N. Mycosis: diagnosis and treatment. A guide for doctors. M.:ViGi Group, 2008. (in Russian).

4. Kunel'skaia V.Ia., Shadrin G.B., Machulin A.I., Krasnikova D.I., Andreenkova O.A. Epidemiological aspects of fungal infection of ENT organs. Advances in medical mycology. 2015; 14 : 143-145 (in Russian).

5. Kunel'skaia V.Ia., Romanenko S.G., Shadrin G.B., Krasnikova D.I. Laryngomycosis. Differential diagnosis.Oncosurgery. 2014; 6: 14-5 (in Russian).

6. Bhandarkar AM, Kudva R., Damry K., Radhakrishnan B. Fungus ball in the nasal cavity mimicking a rhinolith. BMJ Case Rep. 2016. doi: 10.1136/bcr-2016-215490. pre-admission diagnostics of the nasal cavity fungus ball. CBCT allows to define the diagnosis, determine the extent of the lesion, identify individual features of the nasal cavity structure, and plan optimal access during surgery.

Источник финансирования и конфинкт интересов.

Авторы данной статьи подтвердими отсутствие финансовой поддержки исследования и конфмикта интересов, о которых необходимо сообщить.

7. Serova N.S., Evseeva E.V.. Radiodiagnostics of odontogenic maxillary sinusitis. Vestnik Otorinolaryngologii. 2017; 2:46-50. doi:10.17116/otorino201782246-50 (in Russian).

8. Jiang Yan, Gao Jing, SU Wenling J. Significance of differential diagnosis for sinonasal mass by CT value. J Cent South Univ (Med Sci). 2017; 42(1) DOI:10.11817/j.issn.16727347.2017.01.009.

9. Ternovoy S.K., Arablinskiy A.V., Artsybasheva M.V. Diagnosis of diseases of the nasal cavity, paranasal sinuses and upper jaw by computed and magnetic resonance tomography. Radiology-Practice; 4: 4-12 (in Russian).

10. MossaBasha M. et al. The many faces of fungal disease of the paranasal sinuses: $C T$ and MRI findings. Diagn Interv Radiol. 2013; 19 (3):195-200.

11. S.V. Baranskaya, S.A. Karpischenko. Maxillary sinus fungus ball: CT-diagnostics. Luchevaya diagnostika I terapiya. 2014; 4 (5): $62-67$ (in Russian) 